\title{
Dünden Bugüne 23 Nisan Ulusal Egemenlik ve Çocuk Bayramı Etkinlikleri
}

\section{April 23 National Sovereignty and Children's Day Events from Past to Today}

\author{
Prof. Dr. Meryem AKOĞLAN KOZAK ${ }^{(D)}{ }^{1}$, Yüksek Lisans Öğr. Dilek MUTLUiD) 2
}

\section{$\ddot{O} z$}

Bu çalışmada, başlangıçtan bu yana 23 Nisan Ulusal Egemenlik ve Çocuk Bayramı kapsamında yapılan etkinliklerin belirlenmesi amaçlanmıştır. Ayrıca, 100 yıldır kutlanan ve Dünyada ilk çocuk bayramı olan 23 Nisan etkinliklerine farklı bir bakış açısı getirilmeye çalışılmıştır. Bayram kapsamında gerçekleştirilen etkinliklerin belirlenmesi, bu bayramın bir turizm değeri olarak değerlendirilmesi bakımından önemlidir. Derleme niteliğinde olan bu çalışmada bilgilerin toplanması için tarama yöntemi kullanılmıştır. Taramalar, 23 Nisan Bayramı ve tarihçesi ile ilgili kitap, arşiv, gazete, web sayfası, sosyal medya ve makalelerin incelenmesi şeklinde yapılmıştır. Bu süreçte özellikle 23 Nisan kapsamında yürütülen etkinliklere bakılmıştır. Taramalar 10 Mart ve 12 Mayıs 2020 tarihleri arasında yapılmıştır. Yapılan taramalar sonucunda; 23 Nisan Ulusal Egemenlik ve Çocuk Bayramı başlangıçta ulusal olarak yürütülen, sonrasında ise uluslararası çapta yürütülen bir Mega etkinlik haline gelmiştir. Bu bayram kapsamında yapılan etkinlikler, diğer birçok festival, şenlik ve şölenlerde yapılanlardan daha fazla çeşitlilik, ziyaretçi sayısı, gelir sağlama ve ulusal-uluslararası yayılım gösterme gibi artı değerlere sahiptir. Ayrıca, bu bayram önemli bir insan hareketliliği ve tanıtım sağlamakta ve birçok insan bu vesileyle bir araya gelmekte ve birbirlerini ve ülkelerini hatta yörelerini tanıtmaktadır. Bu yönleri ile bu Bayram bir turistik etkinlik olarak ve etkinlik turizm çeşidi olarak dikkate alınabilir.

Anahtar Kelimeler: 23 Nisan Ulusal Egemenlik ve Çocuk Bayramı, turizm, etkinlik

Makale Türü: Araştırma

\begin{abstract}
In this study, it is aimed to determine the activities carried out within the scope of 23 April National Sovereignty and Children's Day since the beginning. It is also trying to bring a different perspective to the April 23 events, which have been celebrated for 100 years and are the first children's festival in the world. Determining the activities carried out within the scope of the festival is important in terms of evaluating this festival as a tourism value. In this review study, scanning method was used to collect information. The scans were made in the form of examining books, archives, newspapers, web pages, social media and articles related to April 23 and its history. In this process, especially the activities carried out within the scope of April 23 were examined. Scans were conducted between 10 March and 12 May 2020. As a result of the scans, April 23 National Sovereignty and Children's Day became a mega event that was conducted nationally and then internationally. In addition, this festival provides significant human mobility and promotion, and many people come together on this occasion and introduce each other and their country, even their region. With these aspects this Holiday can be considered as a tourist event and as a type of event tourism.
\end{abstract}

Keywords: April 23 National Sovereignty and Children's Day, tourism, events

Paper Type: Research

\footnotetext{
${ }^{1}$ Anadolu Üniversitesi, İşletme Fakültesi, mkozak@ anadolu.edu.tr.

${ }^{2}$ Anadolu Üniversitesi, Sosyal Bilimler Enstitüsü, dilek-mtlu@ @otmail.com.
} 


\section{Giriş}

Etkinliklerin tarihi insanlığın tarihi kadar eskidir. Organize edilen ilk etkinliklerin izlerinin, antik dönemine kadar dayandığ görülmektedir. Bilinen ilk etkinlik Yunan Tanrısı Zeus'un onuruna düzenlenen antik olimpiyat oyunlarıdır (Masterman, 2004, s. 9; Tuna ve Akpınar, 2018, s. 265). Anadolu'da ise bilinen en eski etkinlik bir efsane olan ve M.Ö. 4000 yıllarında Afyonkarahisar'ın Dinar ilçesinde bulunan Suçıan Mağarası'nın önünde gerçekleştirilen Marsyas ve Apollon arasında yapılan müzik yarışmasıdır (Demiralp, 2014, s. 90; Hürriyet, 2017). Buna ek olarak kazılar sonucunda kanıtlanabilmiş en eski etkinlik, ise Göktürk uygarlığından bu yana yapılan deve güreşidir (Aydın, 2011, s. 55). Başlangıç yıllarında dini ve sportif amaçlarla yapılan etkinliklerin yıllar içerisinde amaçları değişmeye başlamış, zamanla toplumsal yaşamda spor, iş, eğitim, din, sanat ve kültür amaçlı etkinliklere yönelik talepler artmaya başlamıştır. Etkinlikler yapılış amaçlarına göre çok farklı adlar altında yapılmaktır. Amaçlarına göre bazı etkinlik çeşitleri festivaller, kongreler, şenlikler ve bayramlar olarak sıralanabilir. Etkinlikler ayrıca, ölçeklerine ve temalarına göre olarak da gruplandırılmaktadır (Jago vd., 1998; Getz, 2008; Allen vd., 2011; Van Der Wagen, 2001). Ölçeğe göre etkinlikler; mega, hallmark, büyük ve yerel etkinliklerdir (Allen vd., 2011, s.29). Temalarına göre etkinlikler ise kültürel etkinlikler, sanat ve eğlence etkinlikleri şeklinde sınıflandırılabilmektedir (Quinn, 2009 , s. 5). Bayramlar ise alan yazında festivaller ve şenlikler kapsamında yer alırken, ülkemizde ise bir etkinlik çeşidinden ziyade bir kültürel olay ya da kutlama olarak kabul görmektedir. Bayramlar dini ve milli olmak üzere iki genel sınıfa ayrılırken; özellikle milli bayramlar, içinde birçok faaliyetin yer aldığ 1 bir şenlik ve gösteriler şeklinde gerçekleştirilmektedir. Bu bayramlardan biri de bu y1l 100. kez düzenlenen 23 Nisan Ulusal Egemenlik ve Çocuk Bayramidır.

23 Nisan Ulusal Egemenlik ve Çocuk Bayramı kutlamaları çerçevesinde, birçok etkinliğin gerçekleştirilmesi, milli coşkuyu artırması, ülkemizin yurt dışında tanıtımının yapılması, ülke içinde ve dışından gelen ziyaretçilerle bir hareketliliğe neden olması ve yapıldığ şehirlere ekonomik, sosyal katkılar sağlaması yönüyle adeta bir Mega etkinliktir. Bu bayram aynı zamanda uzun soluklu, uluslararası tanıtımı olan ve ilk çocuk dostu niteliğe sahiptir. Bu bayramı, salt tarih ve kültürel bir değer olarak görmek ve bu kapsamda ele almak ilk etapta doğru bir bakış açısıdır. Ancak bu manevi değerin yanında, bir etkinlik turizmi değeri olarak ele alınması da mümkündür. Çünkü bayramlar da diğer etkinlikler gibi yapıldığı yere ekonomik, sosyalleşme ve kültürel etkileşim yönüyle farklı katkı sunmaktadır. Fakat bugüne kadar yapılan araştırmalara bakıldığında, festivaller, kongreler, anma günleri ve fuarların turizm kapsamında değerlendirildiği görülürken, Bayramların ve 23 Nisan Ulusal Egemenlik ve Çocuk Bayramının turizm kapsamında ele alındığı bir araştırmaya rastlanmamıştır.

Bu çalışmada ise 23 Nisan Ulusal Egemenlik ve Çocuk Bayramı'nın etkinlik turizmi kapsamında düşünülmesi için bir farkındalık yaratılmaya çalışılmaktadır. Başka bir ifadeyle, buradaki amaç, bu bayrama bir turizm değeri olarak kurumların ve araştırmacıların dikkatini çekmektir. Bunun sağlanabilmesi için öncelikle bu Bayram kapsamında başlangıç yıllarından bu yana yürütülen çok çeşitli etkinliklerin bir değerlendirilmesi yapılmıştır. Gerçekleştirilen Bayram etkinliklerinin bilinmesi bu Mega etkinliğin daha iyi açıklanmasına yardımcı olurken; etkinlik turizmi ile ilişkisinin kurulmasını da kolaylaştıracaktır.

Çalışma konu ile ilgili bilgiler detaylı alan yazın taramaları ile elde edilecektir. Bu amaçla kitap, makale, arşiv belgeleri ve çeşitli elektronik belgeler taranacaktır. Bilgilerin sunumunda, öncelikle çocuk ve çocuk bayramlarının felsefesi ortaya koyulurken; sonrasında bu kapsamda yapılan çeşitli etkinliklerin başlangıçtan bu yana yıllar itibariyle bir değerlendirmesi yapılacaktır.

\section{1. Çocuk ve Çocuk Bayramları}

Türk Dil Kurumu (TDK), bebeklik ve erginlik dönemleri arasında bulunan ve gelişme sürecinde olan kişiyi “çocuk” olarak tanımlamaktadır (TDK, 2019). Çoğunlukla, bebekliğin sona 
erdiği 18. ay ile ergenlik dönemi olarak nitelendirilen 12-14 yaşlarına kadar sürdüğü düşünülür. Diğer taraftan, çocukluk dönemi üst sınırının 12 ya da 25 yaş olabileceği görüşleri de mevcuttur (Önal, 2014, s. 19). Literatürde bebeklik dönemi, daha kesin bir kavramken; çocukluk dönemi daha çok sosyokültürel bir kavramdır. Dolayısıyla, diğer sosyokültürel kavramlar gibi toplumsal değerlere, normlara göre farklılık gösterebilmektedir. Bazı toplumlarda "çocuk" olarak tanımlanabilen bir yaş, bazı toplumlarda "yetişkin" olarak tanımlanmaktadır. Dolayısıyla yaş sınırı, zamana, toplumların gelişmişliklerine ve toplumsal algıya göre farklılık gösterebilmektedir. Bir çocuğun büyümesi, eğitimi ve gelişmesi için gerekli olan sürenin uzaması, çocukluk dönemine ilişkin yaş sınırının da artmasına neden olabilmektedir (Günöz, 2007, s. 4).

Tarihsel olarak bakıldığında çocukluğun, Batı'da 16. yüzyılda orta sınıf tarafından ortaya çıkarıldığ1 görülmektedir (Postman, 1995, s. 8). Anadolu'ya bakıldığında ise çocukluk kavramının daha eskiye uzandığ 1 görülmektedir. Konya'nın Çumra ilçesi yakınlarında bulunan Çatalhöyük'te yapılan arkeolojik çalışmalarda M.Ö. 7400-6200 yıllarından kalma oyuncaklar bulunması bunun bir göstergesi olmuştur (Begiç, 2017, s. 17). Batı ülkelerinde çocukların kendilerine ait oyuncak, öykü, müzik ve resim sahibi olmaları 17. yüzyıl itibariyle mümkün olmuştur. Böylelikle, çocuklar, yetişkinlerden ayrılarak; farklı etkinlikler benimsemişlerdir (Önal, 2014, s. 20). Günümüz çocukluk anlayış1, 19. yüzyıl ortalarına kadar gelişerek toplumsal bir olgu haline gelmiştir. 19. yüzyılın bitmesiyle beraber, sosyoekonomik sınıflamalarda kullanılan hem toplumsal hem de biyolojik bir kategori olarak kullanılmaya başlanmıştır (Güler, 2009, s. 12). Bu değişimde, yaşanan ekonomik, sosyal ve sağlıkla ilgili gelişmeler rol oynamıştır. Tarım toplumundan sanayi toplumuna geçiş, çocuk ölümlerinin azalması, toplumdaki aile rolünün ve yapısının değişmesi, orta kademede yer alan toplumsal sınıfın gelişmesi ve insanların kendilerine ayırdıkları zamanın artması bu gelişmelerdendir. Çocuk kavramı 20. yüzyıla gelindiğinde, toplumun geleceğine yön veren birey olarak görülmeye başlanmıştır. "Çocuk yüzyılı" olarak isimlendirilen bu dönem, psikolog, hukukçu, eğitimci ve filozof gibi farklı bilim dallarından kişilerin çocuklar üzerinde çalıştıkları bir dönem olmuştur (Önal, 2014, s. 21). Çocuk hakları kavramı, yine bu dönemde gündeme gelmiş bir kavramdır. Çocuk hakları konusunda yapılan ilk çalışma, Çocuk Hakları Cenevre Bildirgesi olup, 1924'te Milletler Cemiyeti tarafindan kabul edilmiştir. İnsan Hakları Evrensel Sözleşmesi, Birleşmiş Milletler Genel Kurulu tarafından 1948 yılında kabul edilmiş, ancak çocuk hakları ve özgürlüklerine gereği kadar yer verilmediği düşünülerek, çocuklara özgü ayrı bir sözleşme hazırlanması için çalışmalar başlatılmıştır. Bu çalışmalar sonucu, 1959'da, "Çocuk Hakları Sözleşmesi”, 78 ülkenin temsilcilerinin yer aldığ1 Birleşmiş Milletler Genel Kurulu'nda oybirliğiyle kabul etmiştir. 1989'da güncel bir uluslararas1 sözleşmeye gerek duyularak "Birleşmiş Milletler Genel Kurulu Çocuk Hakları Sözleşmesi" hazırlanmış ve 1990'da 61 ülke tarafından kabul edilmiştir. Aynı sözleşme, 1994 yılında, Türkiye Büyük Millet Meclisi tarafından da onaylanmıştır (Aral ve Gürsoy, 2001, s. 27). Resmi Gazetede 27 Ocak 1995 tarihinde yayınlanmış, 4058 sayılı yasa ile iç hukuk kuralına dönüşmüş ve Türkiye'de de uygulanmaya başlanmıştır (T.C. Resmi Gazete, 1995).

Çocuk Hakları Sözleşmesi'nin ardından çocuklara özel bir gün belirlenmesi ile ilgili görüşler başlamıştır. Bakıldığında, ilk Çocuk Bayramı 1857 yılında Chelsea, Massachusetts'teki Rahip Dr. Charles Leonard tarafından Haziran'ın ikinci pazar günü olarak başlatılmışırır. Ancak daha sonra Gül Günü olarak kutlanmıştır. 1925 yılında, Dünya Çocuk Refahı Konferansı sırasında Cenevre'de 1 Haziran'ın Uluslararası Çocuk Bayramı olarak kutlanması önerilmiştir. Ardından BM Genel Kurulu Dünya Çocuk Bayramı'nın, Çocuk Hakları Bildirgesi'ni anmak maksadı ile 20 Kasım'da “Çocuk Günü” olarak kutlanmasını kabul etmiştir (Mezkit, 2019, s. 204). Ancak bazı ülkeler kendi belirledikleri günlerde Çocuk Günü’nü kutlamakta ve bu doğrultuda bazı şenlikler düzenlemektedir. Bu amaçla farklı ülkelerdeki uygulamalara bakıldığında, bu konunu tek bir gün veya tarihte olmadığı dikkat çekmektedir. Tayvan'da 1990 yılından bu yana resmi olarak kutlanan "Çocuk Bayramı" (4 Nisan) ve Temmuz, Ağustos ayında kutlanan çocuk festivalleri (Lu, 2011; CIOFF, 2020; Wikipedia, 2020), Almanya'da 1990 yılından bu yana kutlanmaya başlayan (20 Eylül) "Evrensel Çocuk Günü” (Nationaltoday, 2020), Meksika'da, 1925 yılından beri her yıl kutlanan (30 Nisan) "Çocuk Bayramı" (Notimerica, 2020), Nijerya'da 1964 y1lından bu yana her 
y1l (27 Mayıs) kutlanan "Çocuk Bayramı" (Wikipedia, 2020), Kanada da resmi olarak kutlanan (20 Kasım) "Dünya Çocuk Günü” (Childrensfestival, 2020) ve 1978 yılından bu yana Mayıs'ın son Pazartesi günü başlayan ve 1 hafta süren Vancouver Uluslararası Çocuk Festivali (Burley \& Imbert, 2009, s. 196). Avustralya'daki Ekim ayının dördüncü çarşamba günü yapılan çocuk etkinlikleri (Archive, 2016) bu bayramlara örnek olarak verilebilir.

Türkiye'de çocuk bayramı fikri, 20.yüzyılda Cumhuriyetin ilk dönemlerinde, kötü olan çocuk şartlarına bir dikkat oluşturmak ve çocukları korumak için bir takım kurum ve kuruluşlar tarafından gündeme getirilmiştir. Bunlardan en önemlisi Fuad Bey’in öncülüğünde kurulan Himaye-i Etfal Cemiyeti'dir. Bugünkü adı Çocuk Esirgeme Kurumu olan cemiyet 1908 yılında Kırıkkale'de kurulmuştur. 20. Yüzyılın başından beri İstanbul ve Kırklareli’nde kurulum ve faaliyet çabalarına girmiş, Kurtuluş Mücadelesi boyunca da savaşta şehit düşen ailelerin kimsesiz çocuklarına yardım etme amacıyla 30 Haziran 1921'den itibaren Ankara'da Türkiye Himaye-i Etfal Cemiyeti olarak varlık bulmuştur. 23 Nisan Ulusal Egemenlik ve Çocuk Bayramı bu cemiyetin öncülüğünde 1922 yılında Ankara'da yapılan ilk kutlamalarla başlamıştır (Cantürk, 2018, s. 30). Mustafa Kemal Paşa'nın da bu faaliyetlere destek vermesi ile 23 Nisan, 1925 yılında "Çocuk Günü” olarak 1926 yılından itibaren "23 Nisan Ulusal Egemenlik Bayramı" yanına "Çocuk Bayramı" tabiri de eklenmiştir (Özçelik, 2011, s. 266).

\section{23 Nisan Ulusal Egemenlik ve Çocuk Bayramı Etkinlikleri}

Ülkemizde, 23 Nisan Ulusal Egemenlik Bayramı'na 1926 yılından sonra “Çocuk Bayramı" olarak kutlanmaya başlanmıştır. Bu tarihten itibaren kutlanan bu bayram her ne kadar bir toplumsal mesaj içerse de çocuklar ve diğer katılımcılar için bir bayram, şenliktir. Bu nedenle bu çalışmada, bu bayramların etkinlik yönü ile ele alınması planlanmıştır. Başlangıç döneminden bu yana bu bayramlar kapsamında hangi etkinlikler yapıldı, çocuklar nasıl katıldı ve eğlendi? Temel sorusundan hareketle, günümüze kadar yapılan kutlamalar değerlendirilmiştir.

1927 yılında ilki kutlanan 23 Nisan Ulusal Egemenlik ve Çocuk Bayramı sırasında gerek Himaye-i Etfal Cemiyeti gerekse Mustafa Kemal Paşa ve Başvekil, yarının sahipleri olan çocuklara büyük bir alaka göstermiş ve çocuk gününün bir bayram havası içinde kutlanması için özel çaba sarf etmişlerdir. Mustafa Kemal Paşa otomobillerinden birini törenlerde çocuklara ayırmış ve Cumhurbaşkanlığı bandosunu çocuk sarayında, çocuk bayramı için görevlendirmiştir. Himaye-i Etfal "Şimdiye kadar Türk çocukları, devletin üst düzey yöneticilerinin hiçbirinden bu derece şefkat ve sahiplenme görmediklerinden bu saadete nail olan çocuklarımız ne kadar övünse ve sevinse yeridir." ifadeleriyle Mustafa Kemal Atatürk'ün çocuklara ve Çocuk Bayramı'na verdiği önemi ve desteği dile getirmiştir (Hakimiyeti Milliye, 1927, s. 1). Mustafa Kemal Paşa, daha sonra 23 Nisan'da düzenlenen Himaye-i Etfal balosuna katılarak cemiyete ve çocuklara karş1 sevgisini ortaya koymuş; baloda 10 bin lira yardım toplanmıştır (Gürbüz Türk Çocuğu, 1927, s. 1). Aynı yıl, İstanbul'da Taksim, Beyazıt, Barbaros meydanlarında çok parlak kutlamalar yapılmıştır.

Bayram dolayısıyla Ankara ve İstanbul'da her tarafa Türk bayrakları asılmıştır. Buna ek olarak resmi kurumlar tatil edilmiş ve gece de sokaklar elektrik lambaları ile aydınlatılmıştır. Çocuklar bayramda geçit töreni yapıp spor yarışları ile eğlenmiş aynı zamanda da Himaye-i Etfal'e yardım toplamak için rozet alınması için caddelerde yürüyerek rozet dağıtmışlardır. Rozet dağıtımıyla cemiyete önemli miktarda yardım toplanmıştır (Vakit, 1927, s.1).

1928 yılında, daha önce sadece iki şehirle sınırlı olan kutlamalar, Türkiye'nin diğer illerine de yayılmaya başlamıştır. Bayram, Ankara'nın ve İstanbul dışındaki, İzmir, Samsun, Sivas, Mersin, Adapazar1, Bursa, Edirne, Kütahya gibi illerde de Resmi tatil ve özel merasimlerle kutlanmaya başlanmıştır (Akşam, 1928, s.1). Gerçekleştirilen kutlamalarda, çocuklar bayramın yapılacağı hükümet meydanlarında toplanarak, şiir okuma, bando eşliğinde resmigeçit, halk oyunları gösteri gibi etkinliklerde bulunmuşlardır. 
Çocuk Bayramı 1929 yılına gelindiğinde "Çocuk Haftası" adıyla yedi güne çıkarılmıştır (Cantürk, 2018, s.13). Çocuk Haftası etkinlikleri kapsamında okullar tatil edilmiş ve bu sayede tüm öğrenciler kutlamalara katılabilmiştir. Bir haftaya çıkarılan 23 Nisan kutlamalarını Himayei Etfal Cemiyetinin tek başına yetiştiremeyeceği düşünüldüğünden, bu yılın kutlamalarının genel organizasyonu Türk Ocaklarına verilmiştir. Çocuk Haftasıyla ilgili hazırlıklar Türk Ocakları Genel Merkezi'nde 1 Nisan 1929 tarihinden itibaren yapılmaya başlanmıştır.

Türk Ocakları çocuk haftası için çeşitli etkinlikler düzenleyerek çocukların eğlenmesini sağlamıştır. Buna ek olarak konferanslar verilerek annelere çocuk bakımı eğitimleri düzenlemiştir. 1929 yılında bu etkinlikler kapsamında meme çocuğu, mama çocuğu ve oyun çocuğu çağlarındaki çocuklar arasında "Gürbüz Çocuk Yarışması" da yapılmıştır. Türk ocağ İstanbul için de bir haftalık program hazırlamıştır. Programda 3 gün müsamere, 4 konferans ve bir balo düzenlenmiştir. Müsamereler ve balo tamamen çocuklar tarafından hazırlanmıştır (Cumhuriyet, 1929, s.1). Bu tarihten itibaren çocuklar bu bayram kapsamında artık bir hafta süreyle kutlama yapacaklardır.

1929 yılında yapılan 23 Nisan etkinliklerinde dikkat çeken en önemli gelişme, Ankara'daki törenlere Türkiye'nin değişik yerlerinden çocukların katılımı olmuştur. Bu amaçla Ankara'ya gelen öğrencileri Ankaralı kız ve erkek öğrenciler evlerinde misafir etmiş̧lerdir (İkdam, 1929, s. 3; Sonsaat, 1929, s. 3).

1933 yılında 23 Nisan Çocuk Bayramı'na çocukları gelecekteki sorumluluklarına hazırlayan yeni bir aşama daha eklenmiştir. $\mathrm{Bu}$ süreçte çocukların TBMM'ye ziyaretleri başlamıştır. Buna ek olarak bu yıl Atatürk, 23 Nisan sabahı çocukları makamında ağırlayıp, onlarla sohbet etmiştir (Cantürk, 2018, s. 13). Bu tavır, ileriki yıllarda gelenekselleşerek günümüze kadar sürdürülecektir. Aynı şekilde, Milli Eğitim Bakanı Reşid Galip Bey'in kaleme aldığ1 "Türk'üm-Doğruyum" and1 da çocuklar tarafından 23 Nisan etkinlikleri sırasında stadyumlarda okunmuştur. $\mathrm{Bu}$ ant daha sonraki senelerde okulların bayrak törenlerinde söylenmeye başlanmıştır (Kocatürk, 1988, s. 489). 1934 yılında Himaye-i Etfal Cemiyetinin adı dilde sadeleşmeye gidilmesi üzerine Atatürk tarafindan 'Türkiye Çocuk Esirgeme Kurumu' olarak değiştirilmiştir (Tarımeri, 2018, s. 2).

1938 yılında, Kırşehir ili, Köşker Nahiyesinde yaşanan deprem felaketinden dolayı bayram kutlamaları geçmiş yıllara nazaran daha sakin ve bol yardımlaşma unsurları ile geçmiştir. Atatürk'ün vefatından sonra büyük bir yokluğu hissettirmemek adına 1939 yılı kutlamalarında da çocuk meselelerinde de duyarlılık oluşturmak için özen gösterilmiştir (Temizgüney, 2019, s. 150). 1940’l1 yıllardaki kutlamalar önceki kutlamalara benzer bir şekilde yapılmakla birlikte savaş yılları boyunca özellikle ihtiyaç sahibi çocuklar için yardım kampanyaları devam etmiştir. Ancak halkevlerinin 11 Ağustos 1951 tarihinde kapatılması (T.C Resmi Gazete, 1951) ile Çocuk Bayramı büyük bir destekten yoksun kalmıştır. Buna rağmen, 23 Nisan kutlamalarında aynı coşku yakalanmaya çalışılmışsa da basının ilgisi açısından değerlendirildiğinde diğer önemli gelişmelerin gerisinde kaldığı anlaşılmaktadır.

1959 yılı kutlamaları hava koşulları nedeniyle istenilen coşkuyla geçmemiştir. İstanbul'da Taksim, Beyazıt, Barbaros meydanlarında yapılan törenler kısa tutulmuştur. Taksim'deki törende çocuklar ellerinde büyük bir Atatürk posteri taşımışlardır (Hürriyet, 1959, s. 3). Ayrıca bayram için Fatih ve Selimiye'den 21 pare top atışı yapılmıştır. Törenler resmigeçitle son bulmuştur. Çocuk Esirgeme Kurumu öncülügünde çok sayıda çocuk yuvasının aç1lış1 yapılmıştır. Yine Kızılay'ın fakir çocuklar için yardımları devam etmiş, çocuklar için eğlenceler düzenlemiştir. Ankara'da da törenler havanın yağmurlu olması nedeniyle yapılamamıştır. Her okuldan seçilen kız ve erkek öğrenciler Anıtkabir'i ziyaret etmişler, ardından Sıhhiye, Ulus ve Yıldırım Beyazıt alanlarındaki anıtlara çelenk bırakmışlardır. Hava şartları dolayısıyla törenlerin daha çok okullarda yapılması, şehirdeki kutlamaların sönük geçmesine sebep olmuştur. Ankara Radyosunda Celal Yardımcı ve Refet Aksoy günün anlamına dair birer konuşma yapmışlardır (Hürriyet, 1959, s. 3; Vatan, 1959, s. 1). Çocuk Haftası dolayısıyla çok sayıda balo da tertip 
edilmiştir. Türk-Amerikan Derneği, 23 Nisan münasebetiyle Bulvar Palas Oteli’nde bir çocuk balosu düzenlemiş, Orduevinde ise çocuklar için kukla gösterileri, Karagöz oyunu gibi çeşitli etkinliklerle dolu bir balo yapılacağı duyurulmuştur (Ulus, 1959, s. 1).

Çocuk Esirgeme Kurumu 1970'li yıllara gelindiğinde, amacına ulaşmış 23 Nisan Ulusal Egemenlik ve Çocuk Bayramı, geniş kitleler tarafından kutlanmaya başlamıştır. Bu doğrultu da çocuk bayramı açısından 1970'li yıllar dönüm noktası sayılabilmektedir. TRT Kurumu da 1975 'teki kutlamalara katılarak çocuk programlarını hafta boyunca yayınlamıştır. 1978'de Meclis Başkanlığı'nın izni ile Mecliste düzenlenen törenlere üye sayısı kadar çocuk katılması kararlaştırılmıştır (Akın, 1997, s. 93).

1979 yılı UNICEF tarafindan Uluslararası Çocuk Y1lı ilan edilmiştir. Buradan yola çıkarak TRT Çocuk Programları Müdürü Tekin Özertem ve Yardımcısı Canan Arısoy tarafindan bütün dünya çocuklarını bir araya getirmeyi hedefleyen bir proje düşünülmüştür. TRT Kurumunun üst yönetimi tarafından da onay alındıktan sonra organizasyon çalışmalarına başlanmıştır. Bu doğrultuda 23 Nisan 1979 yılında TRT Uluslararası 23 Nisan Çocuk Şenliği'nin birincisi Türkiye'de beş farklı ülkenin katılımı ile kutlanmıştır. Bu ülkeler; SSCB, Irak, İtalya, Romanya ve Bulgaristan'dır. Uluslararası şenliğe genellikle 8-14 yaşları arasındaki çocuklar katılmıştır. Program yaklaşık olarak 16 Nisan'dan 26 Nisan'a kadar olan 10 günlük bir süreçte yapılmıştır. 1 grupta ortalama 20 çocuk ve 6 lider olacak şekilde organize edilmiştir. Bu çocuklar ve liderleri en geç 15 Nisan'da gelmiş olmaları gerekmektedir. Geldikleri zaman da grup liderleri, TRT tarafından görevlendirilmiş rehberler ile birlikte çalışmıştır. Gelen çocuklar, ilköğretim okulları aracılığı ile kendi yaşlarında bir Türk çocuğu olan ailenin evinde ağırlanmıştır. Bu sayede çocuklara Türk insanının kültürü gösterilmiştir. Ülkelerine döndükleri zamanda kendi ailelerine, çevrelerine ve toplumlarına bu kültürü anlatmaları beklenmektedir. 23 Nisan etkinlik haftası, Ankara'da "şenlik yürüyüşü" ile açılmıştır. Her ülke kendi yöresel kıyafetleri ile kendi müziklerini çalıp dans ederek gösterilerini yapmıştır. Etkinlikler, bütün dünya çocuklarının, bu bayramı Türk ve dünya çocuklarına armağan eden Ulu Önder Atatürk'ün, Anıtkabrini ziyareti ile devam etmiştir. Türkiye Cumhurbaşkanı, TBMM Başkanı ve TRT Genel Müdürü’ne yapılan ziyaretler ile tamamlanmıştır. TRT Uluslararası 23 Nisan Çocuk Şenliği Galası, 23 Nisan günü yapılmıştır. Ülkelerin, yöresel kıyafetleri ile hazırladıkları, ortalama üç dakikalık millî gösterileri, kendi müzikleri eşliğinde yaklaşık 4 saat süren ve canlı olarak yayınlanarak Türk izleyicisine sunulmuştur. Galanın sonunda dünya çocukları bu etkinlikler sayesinde dostluk ve barış duygularıyla bütünleşerek hep birlikte evrensel müzik eşliğinde el ele dans ederek eğlenmişlerdir. Dünya çocukları ülkelerine dönmeden önce 24 ve 25 Nisan'da piknik ve geziler yapılmıştır. Bu sayede Türk ve diğer dünya çocuklarının kaynaşması sağlanmıştır. Bu etkinliklerle aynı zamanda, Türkiye'nin ve misafir severliğimizin Dünyaya tanıtımına katkıda bulunulmaktadır (Archive, 2010). Bu uluslararası etkinliğe 1979'dan bu yana, 90 farklı ülkeden 50 bin kadar çocuk ve yaklaşık 10 bin grup lideri katılmıştır.

1979 Uluslararası Çocuk Yılı kapsamındaki gerçekleşen önemli bir gelişme de TRT'nin düzenlediği Uluslararası 23 Nisan Çocuk Şenliğine gelen beş yabancı ülkenin çocukları ve Ankara'daki çocukların da katılmasıyla TBMM salonunda 1. Dünya Çocuk Parlamentosunun toplanması olmuştur. Sonraki yıllarda, 1987 ikincisi düzenlenen bu etkinliğe 56 ülkenin çocuk temsilcileri katılırken; 3. Parlamento 1999 yılında 44 ülkeden bine yakın çocuğun katılımıyla yapılmıştır (Cantürk, 2018, s. 66). 1979 Uluslararası Çocuk Yı1ı, Milli Eğitim Bakanlığı, TRT, Çocuk Esirgeme Kurumu ve çok sayıda derneğin katkıları ile Türkiye'de çok başarılı geçmiştir. Çocuklara hizmet götürmek duygusuna sahip gönüllülerin katılımı ile oluşan bu yapının dağılmaması ve başlatılmış olan etkinliklerin nitelik kaybetmeden sürdürülebilmesi için bu bayrama işlevlerinin tümüyle sahip çıkacak bir kuruluşun oluşturulması gereği duyulmuş ve "Çocuk Esenliği Vakfı" adında bir vakıf kurulması için girişimlerde bulunulmuştur. Ancak öngörülen vakıf, 1980 yılı ortalarında önemli bir aşamaya geldiği halde, 12 Eylül olayı nedeniyle sonuca gidilememiştir (Aslan, 2000, s. 3). 
19 Mart 1981 tarihine gelindiğinde, Millî Güvenlik Konseyi’nin Ulusal Bayramlar ve Genel Tatiller Hakkındaki Kanun Hükmündeki "23 Nisan Ulusal Egemenlik ve Çocuk Bayramıdır" kararı ile bu bayram resmî bir isme ve statüye kavuşturulmuştur (T.C. Resmi Gazete, 1981, s 2). 1985 'te ise TBMM ve TRT'nin şenliklerine katılan dünya çocuklarının sayılarının git gide artması ile bu bayram Uluslararası nitelik kazanmıştır (Cantürk, 2018, s. 14). 23 Nisan artık Türk çocuklarının dünya çocuklarına hediye ettiği bir gün olmuştur (Bulvar, 1985, s. 3).

1992 Birleşmiş Milletler Rio "yeryüzü zirvesi” ile her ülke kendi Yerel Gündem 21'ini oluşturmaya çağrılmıştır. Gündem 21'in 28. Bölümünde yer alan bu çağrının etkileri Türkiye'de ancak, 1997 y1lı sonunda başlamış ve belediyelerin bünyesinde Kent Konseyleri oluşturulmuştur (Kestellioğlu, 2011, s. 121). Daha sonra ilgili yönetmeliğin 12. maddesine dayanarak Çocuk Meclisleri açılmaya başlamıştır (Yalçınkaya ve Azrak, 2016, s. 154). Çocuk Meclislerinin açılış tarihleri genellikle 23 Nisan tarihine denk getirilmiş ve Türkiye'nin hemen her il ve ilçe belediyelerinde açılmıştır. Çocuk Meclisleri Çocuk Bayramı kapsamında çeşitli etkinlikler düzenleyen bir kuruluş haline gelmiştir. Bu kapsamda 23 Nisan Çocuk Bayramı'nın tarihini anlatan ve aynı zamanda çocukların eğlenmelerini sağlayan dans gösterileri, tiyatro ve oratoryolar, halk oyunları gösterileri, şiir yarışmaları, sihirbaz gösterileri düzenlemektedirler (Mezkit, 2019, s. 205-206). Devlet Tiyatroları Genel Müdürlüğü de bu bayrama tiyatro sanatı ile katkıda bulunmuştur. 2005 yılından beri her yıl 24-29 Nisan tarihleri arasında Ankara'da Devlet Tiyatroları Genel Müdürlüğü tarafından "Küçük Hanımlar Küçük Beyler" Uluslararası Çocuk Tiyatroları Festivali düzenlenmektedir (Cantürk, 2018, s.72).

2013 yılına kadar Ankara'daki törenler Milli Eğitim Bakanlığı tarafindan, illerden gelen temsilci öğrenciler ile öğretmenlerden oluşan heyetin Anıtkabir'i ziyaretiyle başlatılmıştır. Bu tören kapsamında aynı zamanda, Ulus'taki Atatürk Anıtı ve Kızılay'daki Zafer Anıtı ile Atatürk Orman Çiftliği'ndeki anıta da izci ve öğrencilerden oluşan heyetler çelenk koymuşlardır. Bu törenlerin ardından, 19 Mayıs Stadyumu'nda 23 Nisan Ulusal Egemenlik ve Çocuk Bayramı kutlamaları yapılmıştır (Hürriyet, 2002). Ancak 2012 yılında değiştirilen milli bayram kutlama yönetmeliği ile beraber, tören akışında bazı değişiklikler yapılmıştır. Örneğin, 23 Nisan bayramında çocukların devlet adamlarının koltuğuna oturması uygulaması sona ermiş, ilkokul öğrencilerinin stadyum gösterilerinin yerine kapalı spor salonları, alışveriş merkezleri ve parklarda halkın katılımıyla şenlik yapılmasına karar verilmiştir (Sabah, 2013). Ayrıca, etkinlikler belediyeler ya da topluluklar tarafından organize edilmesine başlanmıştır. Çankaya Belediyesi'nin düzenlediği Bin Çocuk Korosu gösterisi ve Devlet Opera ve Balesi Genel Müdürlüğü tarafından hazırlanan çocuk balesi gibi (Hürriyet, 2019).

Mustafa Kemal Atatürk'ün çocuklara armağanı 23 Nisan Ulusal Egemenlik ve Çocuk Bayramı'nın, bu sene 100. Yılı kutlanmıştır. Ancak yaşanan yeni tip koronavirüs (Kovid-19) salgınıyla mücadeleye yönelik tedbirler kapsamında bayram coşkusu bu yıl evlerde yaşanmak zorunda kalmıştır. Bu kapsamda TRT 23 Nisan Çocuk Şenliği için 'Türkiye'nin Çocukları' kampanyası başlatmıştır. 'Videonu çek, TRT'ye gönder, 23 Nisan'da seni bütün Türkiye izlesin' sloganı ile başlayan davete rekor katılım olmuştur. Kampanyaya Türkiye'nin dört bir yanından ve yurtdışından 171 bin 177 çocuk, evlerindeki camları Türk bayrakları ile süsledikleri, şarkı söyledikleri, şiir okudukları, gösteri yaptıkları 23 Nisan videosunu göndermiş̦tir (Hürriyet, 2020). Gönderilen bu videolar 23 Nisan günü, TRT Çocuk' da gün boyu, TRT 1' de 23 Nisan Çocuk Şenliği Gala Programı'nda ve gün boyu program aralarında gösterilmiştir (TRT 23Nisan, 2020). İletişim Bakanının yaptığı çağrı ile 23 Nisan saat 21.00'da balkonlardan İstiklal Marşı okunmuştur (Milliyet, 2020).

Milli Eğitim Bakanlığı (MEB) 100. yılını kutladığımız 23 Nisan Ulusal Egemenlik ve Çocuk Bayramı için özel bir marş hazırlamıştır. Bestesini Gazi Üniversitesi Müzik Bölümü Öğretim Üyesi Orkestra Şefi Doç. Dr. Mehmet Efe, sözlerini Şermin Yaşar ve Mehmet Efe birlikte yazmıştır. Marşın düzenlemesi Serkan Sönmez tarafından yapılmıştır. 100.yıl marşının seslendirmesini ise Gazi Üniversitesi Müzik Bölümü, Hacettepe Devlet Konservatuarı, Prof. Dr. Mehmet Sağlam Ortaokulu, Ulubatlı Hasan Ortaokulu öğrencileri evlerinde yapmışlardır. 100. 
yıl marşına özel bir klip de hazırlanmıştır. Bu klip yaşadığımız koronavirüs pandemisi nedeniyle çocukların çekim ekipleriyle bir araya gelmemesi için görüntüler cep telefonu ile çekilerek önlem alınmıştır (MEB, 2020). Bazı Belediyelerde birtakım etkinlikler düzenlemiştir. "Evimiz Bayram Yeri” sloganıyla Başkentli çocukları 23 Nisan Perşembe günü aileleriyle birlikte balkonlara davet eden Ankara Büyükşehir Belediyesi, açık gezi araçları ile 14.30-17.00 saatleri arasında dolaşarak çocuk şarkıları ve marşları çalmıştır. Aynı zamanda açık gezi araçlarında bulunan animasyon ekiplerinin gösterileri ile balkonlara çıkan çocuklara eğlenceli anlar yaşatmışlardır (Ankara Büyükşehir Belediyesi, 2020). Lüleburgaz Belediyesi de sosyal medya üzerinden "Umudum Yeşersin" etiketi oluşturmuş ve çocukların gelecekten beklentilerini, umutlarını, düşüncelerini bu etiket ile sosyal medya hesaplarından yazmalarını istemişlerdir. Çocukların bu etiket ile yazdıkları notları küçük kağıtlara basılmış ve kağıtlara çeşitli ağaçların tohumları da koyularak uçan balonlarla birlikte 23 Nisan Ulusal Egemenlik ve Çocuk Bayramı'nda gökyüzüne salınmıştır. Ardından yine notların bulunduğu Tohumlar daha sonra düştükleri yerlerde toprağa karışarak yeşerecektir (Sözcü, 2020). Bunlara ek olarak özel sektörden bazı firmalar da internet üzerinden etkinlikler düzenlemiştir. On-line atölyeler, dijital ortamda dinlenmesi ve okunması için sesli çocuk kitapları, 23 Nisan'a özel tiyatro oyunun kaydı, on-line konserler bunlara örnektir (Habertürk, 2020).

\section{Yöntem}

Bu çalışmada, 23 Nisan Ulusal Egemenlik ve Çocuk Bayramı'nın ülkemiz için Milli birlik ve beraberlik ve tarihi açıdan önemi yanında, bir turizm değeri olarak da ele alınabileceğine ilişkin bir farkındalık yaratılmaya çalışılmaktadır. Çalışma, 100 yıldır kutlanan ve Dünyada ilk çocuk bayramı olan 23 Nisan etkinliklerine farklı bir bakış açısı getirmesi bakımından önemlidir.

Derleme niteliğinde olan bu çalışmada tarama yöntemi kullanılmıştır. Tarama yöntemi; geçmişte ya da halen var olan bir durumu betimlemeyi amaçlayan bir araştırma yaklaşımıdır. Araştırmaya konu olan olay, birey ya da nesne, kendi koşulları içinde var olduğu gibi tanımlanmaya çalışılır (Karasar, 2009, s. 77). Taramalar yazılı kaynaklar, gazete, dergi, kitap, ansiklopedi, rapor, mektup, makale vb. yayınlar ile yapılmaktadır. Tarama yönteminde araştırmacıya kolaylık sağlaması açısından anahtar kelime iyi belirlenmelidir (Kozak, 2018, s. 88). Bu gerekliliğe bağlı olarak, taramalarda öncelikle 23 Nisan Bayramının tarihçesi ve felsefi üzerinde duran kitap, arşiv ve makalelere bakılmıştır. Daha sonra, 23 Nisan Bayramı kapsamında yürütülen etkinlikler bağlamında tarama yapılmıştır. Bu amaçla yazılan makale ve bildirilerin yanında, gazete haberleri, sosyal medya haberleri de gözden geçirilmiştir Son olarak, turizmde etkinlikler kapsamında yapılan çalışmalar taranmıştır. Kitap, makale, belge ve çeşitli eserlere ulaşmak için Scholar Google ve YÖK Ulusal Tez Merkezi internet sitesi üzerinden "çocuk", "çocuk bayramı", "23 Nisan" ve "etkinlik turizmi” anahtar kelime olarak kullanılmıştır. Taramalar 10 Mart 2020 ve 12 Mayıs 2020 tarihleri arasında yapılmıştır.

Taramalar sonucunda, konu ile ilgili 11 kitap, 31 makale, 13 arşiv belgesi, 24 Elektronik belgeye ulaşılmıştır. Çalışmanın kurgusu, 1926 ile 2020 yılları arasında kutlanan 23 Nisan Ulusal Egemenlik ve Çocuk Bayramı kapsamında düzenlenen etkinlikler yönünde yapılmıştır

\section{Değerlendirme}

Festivaller, karnavallar, şenlikler, fuarlar, kongreler ve spor karşılaşmaları gibi etkinlikler gerçekleştirildikleri destinasyonlar için birer turistik talep yaratan ve yönlendiren ürünlerdir (Berberoğlu, 2013, s. 122). Bu nedenle, her etkinlik aynı zamanda, sosyo-kültürel olgu olduğu kadar, ekonomik değer yaratan, yöresel, ulusal ve uluslararası hareketliliğe neden olan toplumsal faaliyetlerdir. Etkinliğin yapıldığı yere olan katkısı, etkinliğin kapsamı yanında, katılımcı sayısı ile ortaya çıkar. Örneğin, Vancouver Uluslararası Çocuk Festivali'ne yaklaşık 1,6 milyondan fazla kişinin katıldığ bilinmektedir (Burley \& Imber, 2009, s. 196). Tayvan'daki Uluslararası Çocuk Folklor ve Folkgame Festivali'nin de (YICFFF) 2001'den itibaren 910.000 turist çektiği ve yılda yaklaşık 500 milyon NT \$ civarında gelir sağladığı görülmektedir (Lu, 2011, s. 272). Ekonomik fayda yanında, Antalya Altın Portakal Film Festivali örneğinde olduğu gibi etkinlikler 
yerli halk için bir eğlence ve sosyalleşme firsatı da yaratmaktadır (Ekin, 2011, s. 107). Bunun yanında, milli beraberlik ve bütünlük duygusu veren Çanakkale Savaşlarını Anma ve Kutlama (Sınmaz, 2015, s. 190) ve bu çalışmanın konusunu oluşturan 29 Ekim Cumhuriyet Bayramı (Aydın vd., 2016, s. 261) kutlama etkinlikleri de bulunmaktadır.

23 Nisan Ulusal Egemenlik ve Çocuk Bayramı ülkemizde 1926 yılından bu yana ulusal çapta, 1979 yılından bu yana ise uluslararası çapta kutlanmaktadır. Daha çok tarih ve kültür çalışmalarına konu olan ve Milli şuur ve birlik bağlamında ele alınan bu Bayram, bakıldığında, bir Mega etkinlik olarak aynı zamanda önemli bir hareketliliğe ve turistik faaliyetlere de neden olmaktadır. Örneğin, sadece TRT'nin yapmış olduğu uluslararası festivale bu zamana kadar yaklaşık 50 bin çocuk katılmıştır. Farklı etnik gruplardan öğrencilerin birlikte olması katılımcıların sosyal ve kültürel gelişimine şüphesiz katkı sağlamıştır. Bu çocuklar aynı zamanda, geleceğin birer turisti olma yanında, bugünün de birer kültür elçileridir ve etkinlik için farklı bir ülkeden ülkemize gelen ziyaretçilerdir. Dolayısıyla, böyle bir Mega etkinliğin turistik amaçlarla kullanılmaması ya da bu bayramın bir turistik ürün olarak da ele alınmaması bu çalışmanın temel gerekçesini oluşturmaktadır. 2001 y1lında TRT'nin düzenlemiş olduğu etkinliğe Makedonya'dan katılan Dalibar Zlatkov'un şu ifadeleri çocukların geleceğin birer turisti olduğunu destekler niteliktedir:

"Anne ve babası beni kendi çocukları gibi sevdi. Hüseyin ile çok eğlenmiştik. Aslında ortak konuştuğum bir dil yoktu. Ancak, TRT'nin hazırlayıp dağıttı̆̆l o küçük sözlükle çok şey anlatabiliyorduk. Onların verdiği ve halen sakladiğım pek çok hediye var. Bende onlara hediye götürmüş̧ı̈̈m. $O$ zamanlar internet yoktu ve uzun süre telefon ile görüş̧ük. Şimdi iki çocuk babasıyım ve kızlarım büyüyünce belki onlarda TRT Çocuk Şenliği'ne katılırlar. Bu yıl Kuşadası'na tatile gitmeyi planlıyorum. Eğer onları bulursam kendilerini Makedonya ya davet edeceğim."(Cantürk, 2018, s. 64).

Çocuk bayramları, çocukların önemsenmesi ve çocuk olgusuna dikkat çekmesi yanında, birey olarak ebeveynlerin tatile çıkma, aktiviteler, zamanlama ve destinasyon gibi konularda da söz sahibi olmalarına da katkı sağladığı da görülmektedir (Jenkins, 1978). Ülkemizde, Çakıcı ve İyitoğlu (2010) ve Aymankuy ve Ceylan (2012) tarafından yapılan araştırmalarda da ailelerin çocuklarının tatil satın alma kararında aile içi katılımlarının olduğu belirlenmiştir. Bu durumu, 2002 yılındaki TRT'nin etkinliğine Azerbaycan'dan katılan Raşide Memmedova şu sözlerle dile getirmektedir:

“Azerbaycan’ı Tebessüm Dans Grubu ile temsil etmiştim. Okula geldik ve kimin hangi evde kalacă̆ açıklandı. İnanın o gün yaşadı̆̆ım heyecanı unutmak çok zor. Çünkü daha bir bilmiyorsun kimin evinde kalacaksin ve bu iki haftayı kimlerle nasıl geçireceksin? Yeni ev, yeni aile çok farklı herşey. Birkaç gün sonra alışıyorsun. Ankara'da Anıtkabir' i ziyaret etmiştik. Sonra o zamanki Cumhurbaşkanı Ahmet Necdet Sezer bizi kabul etti. 2003 yılında İzmir'de gerçekleşen 23 Nisan çocuk etkinliklerine de katıldım. Kaldığım ailenin Ece ismindeki kızları beni çok güzel ăgırladı. Alsancak, Saat Kulesi, İzmir'in deniz kenarı parkı çok güzel. Daha sonra Ankara'da TBMM'yi ziyaret ettik. Büyük konserimiz oldu. Piknik yapılmıştı bizim için, yeni arkadaşlar edindim. En zoru ise veda oldu. Son gala konser gecesinde İstiklal Marşl seslendirildi ve ben gözyaşlarıma hakim olamadım. O zaman iki hafta misafirleri olduğum aile ile yaşıyordum ve kendime şu soruyu sordum: Acaba bir daha bu aile ile yollarımı kesişecek mi? 8 yll sonra ben Ece'yi buldum. Ailem ile İzmir'e tatile gitmistik ve onunla buluştum. Uzun uzun sohbet ettik. Hatıra fotoğrafi çektirdik. Daha sonra Ece ile hep telefonda görüşük. Çocukluk yıllarını hatırladık. Bizim için çok hoş ve güzel anılardı." (Cantürk, 2018, s. 58).

23 Nisan Ulusal Egemenlik ve Çocuk Bayramı'ndaki etkinlikler 2013 y1lına kadar stadyumlarda Milli Eğitim Bakanlığı tarafından, illerden gelen temsilci öğrenciler ile öğretmenlerden oluşan heyetin düzenlediği dans gösterileri, şiir okumaları ve bandolu resmigeçit törenleri ile yapılmaktaydı. 2012 yılında değiştirilen milli bayram kutlama yönetmeliği ile ilkokul ögrencilerinin stadyum gösterilerinin yerine kapalı spor salonları, alışveriş merkezleri ve 
parklarda halkın katılımıyla şenlik yapılmasına karar verilmiştir ve etkinlikler belediyeler ya da topluluklar tarafından organize edilmeye başlamıştır. Bunun sonucunda da etkinlik sayılarında artış olmuştur. Bazı belediyeler koro gösterileri düzenlerken bazı belediyeler tiyatro gösterileri yapmış bazı alışveriş merkezlerinde çocuklara özel konserler düzenlenirken bazı alışveriş merkezlerinde de kukla gösterileri yapılmış, boyama atölyeleri oluşturulmuştur.

2020 yılında ise Covid-19 pandemisi nedeniyle etkinlikler sanal olarak düzenlenmiş ve internet ile televizyonlar üzerinden evlerde yürütülmüştür. Bu organizasyonların önemli kısmı TRT tarafından düzenlenmiştir. Bu kapsamda; çocuklar şarkılar söylemiş, şiirler okumuş, dans gösterileri yapmışlardır. Bazı özel sektör firmaları da on-line atölyeler, dijital ortamda dinlenmesi ve okunması için sesli çocuk kitapları, 23 Nisan'a özel tiyatro oyunun kaydı ve on-line konserler düzenlemişlerdir. Çağımızdaki dijitalleşme bu çocuk dostu olan milli bayramın 100. Yılında kutlanmasını engelleyememiş, Bayram yine coşku ile evlerden ve balkonlardan yapılan katılımlarla kutlanmıştır

\section{Sonuç}

Çocuk kavramı toplumdan topluma değişmektedir. Genel bir tanımla bebekliğin sona erdiği ergenliğin başladığı döneme kadar olan evredir. 19. Yüzyıla kadar ayrı bir birey olarak değerlendirilmeyen çocuk, yüzyılın ikinci yarısından itibaren bir biyolojik kategori olarak tanımlanmaya başlamıştır. 20. Yüzyılda da Birleşmiş Milletler Cemiyeti tarafından, Çocuk Hakları sözleşmesi kabul edilmiştir. Sözleşmeyi kabul eden cemiyet 1989 yılında çocuklar için özel bir gün oluşturulması fikrini ortaya atmış ve bazı ülkeler kendi belirledikleri tarihlerde çocuk bayramını kutlamaya başlamıştır. Ancak Ülkemizde bu gelişmelerin çok öncesinde bir çocuk bayramı fikri doğmuştur. Bilindiği gibi 23 Nisan Ulusal Egemenlik ve Çocuk Bayramı 1926 yılından beri kutlanmaktadır. Atatürk geleceğin güvencesi olarak gördüğü ve önemsediği çocuklara bu bayramı hediye etmiştir. 23 Nisan Çocuk Bayramında; şiir okuma, bando eşliğinde resmigeçit, halk oyunları gösterisi, yarışmalar, balolar ve konser etkinlikleri yapılmaktadır. 1979 yılında TRT'nin 5 ülkeyi 23 Nisan etkinliklerine davet etmesi ile bu etkinlik uluslararası bir boyuta taşınmıştır. Günümüzde TRT'nin düzenlediği 23 Nisan Şenliğine katılan ülke sayıs1 90'ını bulmuştur. Ancak 2020 yılı bayram kutlamaları Covid-19 pandemisi nedeniyle sanal olarak evlerden kutlanmıştır. Bu kutlamalara ayrıca, 22 ülkenin 29 şehrinden çocuklar, 23 Nisan coşkusunu mesajlarıyla paylaşmışlarıdır (Sabah, 2020). Bu kutlamalarla ilgili olarak, KidZania İstanbul CEO'su:

"Meksika'dan Katar'a, Ingiltere'den Misır'a, Kore'den Brezilya'ya, Tayland'dan Türkiye'ye kadar KidZania'nın minik vatandaşlarını, fiziksel olarak bir arada olamasa da bayram coşkusunu doyasıya kutladıklarını" söylemiştir.

23 Nisan Ulusal Egemenlik ve Çocuk Bayramı, bakıldığında başlangıçta sadece Ankara ve İstanbul illeri kapsamında yürütülmüş olsa da kısa zaman da ulusal sonrasında ise uluslararası çapta yürütülen bir Mega etkinliğe dönüşmüştür. Bu bayram kapsamında yapılan etkinlikler, diğer birçok festival, şenlik ve şölenlerde düzenlenen; faaliyet çeşidi, ziyaretçi sayısı, gelir ve ulusaluluslararası yayılım konularında artı değerlere sahiptir. Ayrıca, bu bayram önemli bir insan hareketliliği ve tanıtım sağlamakta ve birçok insan bu vesileyle bir araya gelmekte ve birbirlerini ve ülkelerini hatta yörelerini tanıtmaktadır. Günümüz turizm çeşitleri içerisinde önemli bir yere sahip olan etkinlik turizm bu bağlamda yapılan birçok karnaval, kongre, festival ve bayramları kapsamaktadır.

Son söz olarak; ülkemizde ve Dünyada önemli bir yayılıma sahip olan, bilinen bu tek çocuk bayramı, aynı zamanda ülkemizin bir turizm değeri olarak ele alınabilir mi? Ülkemizin turistik tanıtımında bir "çocuk dostu" etkinlik olabilir mi? bu çalışma ile araştırmacılara bu konuda bir açılım ve farkındalık sağlanmaya çalışılmaktadır. 


\section{Kaynakça}

Akın, V. (1997). 23 Nisan Millã Hakimiyet ve Çocuk Bayramı'nın tarihçesi. Pamukkale Üniversitesi Eğitim Fakültesi Dergisi, 3(3), 91-96.

Akşam Gazetesi, 25 Nisan 1928. Milli Kütüphane Arşivi, Ankara.

Allen J., O'Toole W., McDonnell I. \& Harris R., (2011). Festival and special event management (Fifth Edition), John Wiley and Sons Ltd., Milton Queensland Australia,

Ankara Büyükşehir Belediyesi, (2020). https://www.ankara.bel.tr/haberler/buyuksehirdenbaskentli-cocuklara-ozel-23-nisan-kutlamasi/ (Erişim tarihi: 10.04.2020)

Aral, N., ve Gürsoy, F. (2001). Çocuk hakları çerçevesinde çocuk ihmal ve istismarı. Milli Eğitim Dergisi, 151(5), 27-54.

Archive, 2010

http://web.archive.org/web/20100428025859/http://www.trt.net.tr/23Nisan/tarihce.aspx? (Erişim tarihi:01.05.2020).

Archive, 2016

https://web.archive.org/web/20170608030940/http://www.childrensweek.org.au/whatchildren.php (Erişim tarihi: 03.05.2020).

Aslan, İ. (2000). Cumhuriyet dönemi kültürel miraslarımızdan 23 Nisan çocuk bayramı. Türk Kültürü ve Hacı Bektaş Velî Araştırma Dergisi, 13.

Aydin, A. F. (2011). A brief introduction to the camel wrestling events in western Turkey. Camel conference at SOAS. University of London 55-60

Aydın, M. K., Aydın, M., ve Kaya, F. (2016). Malatya halkevi öncülüğünde kutlanan 29 Ekim Cumhuriyet Bayramı etkinlikleri (1932-1951). Electronic Turkish Studies, 11(18).

Aymankuy, Y., ve Ceylan, U. (2013). Ailelerin turistik ürün satın alma karar sürecinde çocukların rolü (Yerli turistler üzerinde bir araştırma). Elektronik Sosyal Bilimler Dergisi, 45(12), 105122.

Begiç, H. N. (2017). Anadolu'da yaşatılmaya çalış1lan ahşap oyuncak üretimine bir örnek; Dedemin Oyuncakları Atölyesi. Motif Akademi Halkbilimi Dergisi, 10(19), 15-26.

Berberoğlu, T. (2013). Etkinliklerin destinasyona etkileri: 2011 Erzurum universiade kış oyunları (Yayımlanmamış yüksek lisans tezi). Dokuz Eylül Üniversitesi, İzmir.

Bulvar Gazetesi, 1985. Milli Kütüphane Arşivi, Ankara.

Burley, P. \& Imbert, D.S. (2009). The vancouver international children's festival, Canada: reflections on the coordination of a successful event volunteer program. Holmes, K., \& Smith, K. (Ed), Managing Volunteers in Tourism içinde, 195-203, USA: Routledge.

Cantürk, C. (2018). Çocuk bayramı. Ankara: Yade Yayınları.

Childrensfestival, 2020 https://www.childrensfestival.ca/about/ (Erişim tarihi: 03.05.2020).

CIOFF, (2020). http://www.cioff.org/events-festival.cfm/fr/799/Chine_TaipeiYilan_Intern._Children_s_Folklore_\%26_Folkgame_Festival_YICFFF_(Erişim tarihi: 03.05.2020).

Cumhuriyet Gazetesi, 1 Nisan 1929. Milli Kütüphane Arşivi, Ankara.

Çakıcı, C. ve İyitoğlu, Ö. G. V. (2012). Tatil kararlarında aile üyelerinin rolü: Antalya ilinde tatil yapan aileler üzerine bir araştırma. Çukurova Üniversitesi Sosyal Bilimler Enstitüsü Dergisi, 21(1), 117-134. 
Çakır, G. (2019). Atatürk Dönemi’nde çocuk, kadın ve aile algısı (Yayımlanmamış doktora tezi). Dokuz Eylül Üniversitesi, İzmir.

Çelebi, M. (2004). Atatürk'ün himayesinde kurulan Türk maarif cemiyeti. Tarih Incelemeleri Dergisi, 19, 35-53.

Demiralp, D. (2014). İlkçağ Anadolu'sunun Frigya yöresinden yükselen bir hüzün tınısı-Antik metinlerin 1şı̆̆ında Satyr Marsyas' in trajik öyküsü. LAÜ Sosyal Bilimler Dergisi, 5(1), 88104.

Ekin, Y. (2011). Etkinlik turizmi kapsamında festivaller ve Antalya Altın Portakal Film Festivali'nin yerel halk üzerindeki sosyal etkileri konulu bir araştırma. (Yayımlanmamış doktora tezi), Akdeniz Üniversitesi, Antalya.

Koç, B. T. D., ve Güdek, M. Y. (2012). Modernleşme döneminde Osmanlı'da çocuk eğitimi ve literatürü (Yayımlanmamış doktora tezi). Ankara Üniversitesi, Ankara.

Getz, D. (2008). Event tourism: definition, evolution, and research. Tourism Management, 3 (29): 403-428

Güler, B. (2009). Televizyon yayınlarında çocuk ve çocuk sorunlarının işlenişi: TRT'de çocuk temeli yayınların analizi (Yayımlanmamış doktora tezi). Selçuk Üniversitesi, Konya.

Günöz, M. (2007). Türkiye'de çocuk işçiliği sorunu ve çözüm önerileri (Uzmanlık tezi). T.C. Çalışma Ve Sosyal Güvenlik Bakanlığı Türkiye İş Kurumu Genel Müdürlüğü, Ankara.

Gürbüz Türk Çocuğu Gazetesi, Nisan 1927. Milli Kütüphane Arşivi, Ankara.

Habertürk, 23.04.2020 https://hthayat.haberturk.com/23-nisan-2020-etkinlikleri-1073822 (Erişim tarihi: 24.04.2020).

Hâkimiyet-i Milliye Gazetesi, 22 Nisan 1927. Milli Kütüphane Arşivi, Ankara.

Hürriyet Gazetesi, 23 Nisan 1959. Milli Kütüphane Arşivi, Ankara.

Hürriyet Gazetesi, 24 Nisan 1959. Milli Kütüphane Arşivi, Ankara.

Hürriyet, 22.04.2002. http://www.hurriyet.com.tr/gundem/23-nisan-programi-67099 (Erişim tarihi: 29.04.2020).

Hürriyet, 07.03.2017. https://www.hurriyet.com.tr/kitap-sanat/apollon-ile-marsyasin-kapistigidinarda-muzik-yarismasi-sirasi-cocuklarda-40361657 (Erişim tarihi: 07.11.2020).

Hürriyet, 23.04.2019. https://www.hurriyet.com.tr/yerel-haberler/ankara/cosku-dolu-23-nisan41191272 (Erişim tarihi: 29.04.2020).

Hürriyet, 23.04.2020 https://www.hurriyet.com.tr/galeri-trt-23-nisan-videolari-ne-zamancikacak-trt-23-nisan-videolari-saat-kacta-yayinlanacak-41501410 (Erişim tarihi: 25.04.2020).

İkdam Gazetesi, 24 Nisan 1929. Milli Kütüphane Arşivi, Ankara.

Jago, L., Dwyer, L., Lipman, G., Lill, D. V., ve Vorster, S. (2010). Optimising the potential of mega-events: an overview. International Journal of Event and Festival Management, 1 (3): 220-237

Jenkins, R. L. (1978). Family vacation decision-making. Journal of Travel Research, 16(4), 2-7.

Karasar, N. (2009). Bilimsel araştırma yöntemleri. Ankara: Nobel Yayıncılık.

Kestellioğlu, G. (2011). Yerel demokrasi ve kent konseyleri: Kahramanmaraş örneği. Kahramanmaraş Sütçü İmam Üniversitesi İktisadi ve İdari Bilimler Fakültesi Dergisi, 1(1), 121-140. 
Kocatürk, U. (2000). Atatürk ve Türkiye Cumhuriyeti tarih kronolojisi 1918-1938. (3. Bask1). Ankara: Türk Tarih Kurumu Basımevi.

Kozak, M. (2018). Bilimsel araştırma: tasarım, yazım ve yayım teknikleri. Ankara: Detay Yayıncilik

Kuşlu, M. ve Özer, B. (2012). Yerel yönetimlerdeki yönetim bilgi sistemleri ve karar destek süreçleri: Manisa Belediyesi örneği. Celal Bayar Üniversitesi Sosyal Bilimler Dergisi, 10 (1), 389- 410.

Lu, H. Y. (2011). 'Children's Dreamland': constructing national identity through a children's festival in post-authoritarian Taiwan. Journal of Tourism and Cultural Change, 9(4), 271-285.

Masterman, G., 2004, Strategic Sports Event Management. Elsevier Butterworth Heinemann.

McNeal, J. U., \& Yeh, C. H. (1997). Development of consumer behavior patterns among Chinese children. Journal of consumer marketin, 14(1), 45-59.

Milliyet, 23.04.2020 https://www.milliyet.com.tr/gundem/23-nisanda-balkonda-istiklal-marsisaat-kacta-okunacak-istiklal-marsi-ne-zaman-okunur-6196284 (Erişim tarihi: 25.04.2020).

Milli Eğitim Bakanlığı, 2020 http://www.meb.gov.tr/mill-egitim-bakanligindan-23-nisana-100yil-marsi/haber/20745/tr (Erişim tairihi: 10.04.2020).

Mezkit, S. G. (2019). Millî kimliğin oluşturulması bağlamında 23 Nisan ulusal egemenlik ve çocuk bayramı (Yayımlanmamış doktora tezi) Hacettepe Üniversitesi, Ankara.

Nationaltoday, 2020 https://nationaltoday.com/german-world-childrens-day/ (Erişim tarihi: 05.05.2020).

Notimerica, 2020 https://www.notimerica.com/sociedad/noticia-celebra-dia-nino-mexico-30abril-20180430130047.html (Erişim tarihi: 05.05.2020).

Okay, C. (1998). Osmanlı çocuk hayatında yenileşmeler 1850-1900. İstanbul: Kırkambar Yayınları.

Önal, M. (2014). Cumhuriyet dönemi halka yönelik politikalar içerisinde “çocuk” 1923-1938 (Yayımlanmamış yüksek lisans tezi). Dokuz Eylül Üniversitesi, İzmir.

Özçelik, M. (2011). 23 Nisan Çocuk Bayramı'nın ortaya çıkışı ve 1922-1929 yılları arasında 23 Nisan kutlamaları. Gazi Akademik Bakış, (09), 265-284.

Özer, Y. E. (2013). Çocuk hakları, katılım ve yerel düzeyde uygulaması: Türkiye örneği. C. $\ddot{U}$. İktisadi ve İdari Bilimler Dergisi, 14 (1), 245-258.

Öztan, G. G. (2013). Türkiye'de Çocukluğun Politik İnşası. İstanbul: Bilgi Üniversitesi Yayınları.

Postman, N. (1995). Çocukluğun yokoluşu. (K. İnal, Çev.). Ankara: İmge Yayınları.

Quinn, B. (2009). Festivals, events and tourism. London: The Sage Handbook of Tourism Studies.

Sabah, 06.04.2013 https://www.sabah.com.tr/gundem/2013/04/06/23-nisanda-koltuk-devri-bitti (Erişim tarihi: 29.04.2020).

Sabah, 2020 https://www.sabah.com.tr/video/haber/dunyanin-dort-bir-yanindaki-cocuklar-23nisanin-100uncu-yilini-boyle-kutladi-video (Erişim tarihi: 25.04.2020).

Sınmaz Sönmez, C. (2015). Çanakkale Savaşları'nı anma ve kutlama etkinlikleri (1916-1938). http://acikerisim.lib.comu.edu.tr:8080/xmlui/bitstream/handle/COMU/1377/Cahide_S\%c4\% b1nmaz_S\%c3\%b6nmez.pdf?sequence=1\&isAllowed=y (Erişim tarihi: 28.04 .2020$)$

Sonsaat Gazetesi, 16 Nisan 1929. Milli Kütüphane Arşivi, Ankara. 
Sözcü, 22.04.2020 https://www.sozcu.com.tr/2020/gundem/23-nisan-kutlamalari-dijital-ortamatasindi-5766016/ (Erişim tarihi: 23.04.2020).

Tarımeri, N. (2018). Himaye-İ Etfal Cemiyeti’nden Türkiye Çocuk Esirgeme Kurumu'na. http://sosyalhizmetuzmanlari.com/Uploads/MakaleFile/3105fa01-53a9-4964-9e25-

93c42724a014.pdf (Erişim tarihi: 10.03.2020).

TBMM Zabit Ceridesi, 1928

https://www.tbmm.gov.tr/tutanaklar/TUTANAK/TBMM/d03/c005/tbmm03005001.pdf (Erişim tarihi: 15.03.2020).

T.C. Resmi Gazete 1951 https://www.resmigazete.gov.tr/arsiv/7882.pdf (Erişim tarihi: 22.04.2020).

T.C. Resmi Gazete 1981 https://www.resmigazete.gov.tr/arsiv/17284.pdf (Erişim tarihi: 22.04.2020).

T.C. Resmi Gazete, 1995 https://www.resmigazete.gov.tr/arsiv/22184.pdf (Erişim tarihi: 23.04.2020).

Temizgüney, F. (2019). Demokrat Parti Dönemi 23 Nisan Milli Hâkimiyet ve Çocuk Bayramı Kutlamaları. Atatürk Üniversitesi Sosyal Bilimler Enstitüsü Dergisi, 23(1), 145-172.

TRT, 23Nisan, 2020 https://twitter.com/trt23nisan/status/1253289087760506880/photo/1 (Erişim tarihi: 05.05.2020).

Tuna, M. ve Akpınar, A. (2018). Etkinlik Turizmi. Aydın, Ş. ve Boz, M. (Ed.). Turizmde Güncel Konu ve Eğilimler II içinde, 265-284 Ankara: Detay Yayıncılık.

Türk Dil Kurumu, (2019). https://sozluk.gov.tr/ (Erişim tarihi: 12.03.2020).

Ulus Gazetesi, 21 Nisan 1959. Milli Kütüphane Arşivi, Ankara.

Ulus Gazetesi, 24 Nisan 1959. Milli Kütüphane Arşivi, Ankara.

Vakit Gazetesi, 24 Nisan 1927. Milli Kütüphane Arşivi, Ankara.

Van Der Wagen, L. (2001). Event management: for tourism, cultural, business and sporting (2. b.). Frenchs Forest, Nsw: Pearson Education Australia.

Vatan Gazetesi, 24 Nisan 1959. Milli Kütüphane Arşivi, Ankara.

Wikipedia, (2020). https://en.wikipedia.org/wiki/Children's_Day (Erişim tarihi: 05.05.2020).

Yalçınkaya, E., ve Azrak, Y. (2016). Sosyal bilgiler öğretmenlerinin çocuk meclislerine ilişkin görüşleri: nitel bir çalışma. Zeitschrift für die Welt der Türken/Journal of World of Turks, 8(1), 151-169.

Yılmaz, Ş. (2009). Osmanlıdan Cumhuriyete slbyan mekteplerinde yenilik ve gelişmeler (Yayımlanmamış yüksek lisans tezi). Selçuk Üniversitesi, Konya.

\section{ETİK ve BİLIMSEL İLKELER SORUMLULUK BEYANI}

$\mathrm{Bu}$ çalışmanın tüm hazırlanma süreçlerinde etik kurallara ve bilimsel atıf gösterme ilkelerine riayet edildiğini yazar(lar) beyan eder. Aksi bir durumun tespiti halinde Afyon Kocatepe Üniversitesi Sosyal Bilimler Dergisi'nin hiçbir sorumluluğu olmayıp, tüm sorumluluk makale yazarlarına aittir. 